\title{
Pentingnya Kepedulian Sosial di Setiap Musibah dan Bencana Serta Meringankan Ekonomi di Tengah Maraknya Wabah Virus Covid19
}

\author{
Muhamad Ripki ${ }^{1}$ \\ ${ }^{1}$ Mahasiswa Ilmu Al-Qur'an dan Tafsir \\ Universitas Islam Negeri Sultan Maulana Hasanuddin Banten \\ mr17alfatih@gmail.com
}

\begin{abstract}
Disaster is a sad event or event that befalls humans that are unwanted, such as illness, natural disasters, loss in commerce, etc., all of which lead to one meaning, namely badness. Thus, the word disaster in public opinion is only used for things in the form of ugliness and ugliness. Discussion of disasters is inseparable from disasters, discussion of disasters is found in the Koran and Hadith, calamities that occur are often associated because of the causes and consequences of human activity itself, from this statement people think that disasters that often occur every year are caused by the punishment sent down by Allah SWT. to admonish humans. Disasters or calamities occur not only because of human hands, but there are natural factors and destiny that cause disasters to befall humans on earth. But even so, humans must maintain the environment in order to minimize disasters that occur from time to time without being able to predict by technology. Natural disasters are one of the provisions of Allah S.W.T. that occurs in the universe (sunnatullah fi al-kaun) and cannot be separated from the element of cause and effect (causality) as one proof of His power.
\end{abstract}

Keywords : Disaster, Environment, Human 


\begin{abstract}
Abstrak
Musibah sebagai suatu kejadian atau peristiwa menyedihkan yang menimpa manusia yang tidak dikehendaki datangnya seperti sakit, bencana alam, rugi dalam perniagaan, dan lain sebagainya yang kesemuanya menjemurus pada satu makna yaitu keburukan. Dengan demikian, kata musibah dalam opini masyarakat hanya dipakai pada hal-hal yang berbentuk keburukan dan kejelekan. Pembahasan musibah tidak lepas dari bencana, pembahasan musibah terdapat pada Alquran dan Hadis, musibah yang terjadi sering dikaitkan karena adanya sebab akibat dari ulah manusia itu sendiri, dari pernyataan tersebut masyarakat mengira bahwa bencana yang sering terjadi setiap tahunnya disebabkan oleh azab yang diturunkan oleh Allah SWT untuk menegur manusia. Bencana atau musibah terjadi bukan hanya karena ulah tangan manusia, melainkan ada faktor alam dan takdir yang menyebabkan adanya bencana yang menimpa manusia di muka bumi. Tetapi meskipun begitu manusia harus tetap menjaga lingkungan agar dapat meminimalisir bencana yang sewaktu-waktu terjadi tanpa bisa diprediksi oleh tekhnologi. Bencana alam adalah salah satu ketentuan Allah S.W.T. yang terjadi di alam semesta (sunnatullah fi al-kaun) dan tidak terlepas dari unsur sebab akibat (kausalitas) sebagai salah satu bukti kekuasaan-Nya.
\end{abstract}

\title{
Kata Kunci :Musibah, Lingkungan, Manusia
}




\section{PENDAHULUAN}

Negara Indonesia yang terbentang dari Sabang sampai Merauke berjajar pulau-pulau dengan komposisi dan konstruksi yang beragam. Di pulau-pulau tersebut berdiam penduduk dengan ragam suku bangsa, bahasa, budaya, agama, adat istiadat, dan keberagaman lainnya ditinjau dari berbagai aspek, dan memiliki 5 agama (Islam, Kristen Katolik, Kristen Protestan, Hindu dan Budha) yang diakui resmi oleh Pemerintah. Keragaman budaya di Indonesia merupakan sesuatu yang tidak dapat dipungkiri keberadaannya. Namun keberagaman Suku Bangsa dan bahasa tersebut dapat disatukan dalam satu bangsa, bangsa Indonesia, dan satu bahasa persatuan, bahasa Indonesia. Manusia pada dasarnya adalah mahluk sosial. Dalam kondisi demikian, kepedulian sosial menjadi penting untuk dibiasakan. Dalam kehidupan bermasyarakat manusia harus saling menghormati, mengasihi dan peduli terhadap berbagai macam keadaan disekitarnya. Kepedulian seseorang tidak tumbuh begitu saja tanpa adanya rangsangan baik itu melalui pendidikan ataupun pembiasaan. Kepedulian Sosial merupakan sikap memperlakukan orang lain dengan penuh kebaikan dan kedermawanan, peka terhadap perasaan orang lain, sikap membantu orang yang membutuhkan pertolongan, tidak pernah berbuat kasar, dan tidak menyakiti hati orang lain. ${ }^{1}$

Kepedulian ini merupakan sikap memperhatikan sesuatu yang bukan bermaksud untuk ikut campur dalam urusan orang lain melainkan membantu menyelesaikan permasalahan dengan tujuan kebaikan sehingga akan terciptanya keseimbangan sosial. Kepedulian sosial akan menimbulkan sikap sosial, dimana sikap social adalah kesadaran individu yang menentukan perbuatan nyata untuk bertingkah laku dengan cara tertentu terhadap orang lain dan mementingkan tujuan-tujuan sosial dari pada tujuan pribadi dalam kehidupan masyarakat, seperti saling membantu, saling menghormati, saling berinteraksi, dan sebagainya. Islam sebagai agama yang lengkap (kaffah) yang ajarannya meliputi berbagai aspek sebagaimana dijelaskan dalam Al-Qur'an, harus tampil memberikan solusi terhadap tragedi kemanusiaan ini. Hadits sebagai sumber ajaran ke dua dalam Islam setelah Al-Qur'an memiliki norma lengkap yang mengatur atau meberikan petunjuk praktis kepada pemeluk agama Islam dalam menghadapi berbagai wabah termasuk pandemi Covid-19 ini. Petunjukpetunjuk itu meliputi tata cara untuk memproteksi diri dan masyarakat dari terpapar wabah, menyikapi wabah itu sendiri, termasuk menyikapi dan cara dan memperlakukan manusia yang meninggal karena wabah. ${ }^{2}$

${ }^{1}$ Idris Mahmudi, Amd.Kep; M.Pd.I., "ISLAM, BUDAYA GOTONG ROYONG DAN KEARIFAN LOKAL", Penguatan Komunitas Lokal Menghadapi Era Global Strengthening Local Communities Facing the Global Era, hlm. 450 dalam http://jurnal.unmuhjember.ac.id/index.php/pslcf/article/view/925 diakses 2017

${ }^{2}$ Abulsyani, Sosiologi Skematika Teori danTerapan, (PT Bumi Aksara: Jakarta, 2012 ), hlm. 182 


\section{PEMBAHASAN}

A. Mengenali Wabah Virus Corona Dalam Tinjauan Islam

Wabah penyakit dalam Islam merupakan suatu ketetapan dari Allah SWT, setiap wabah yang muncul saat ini tidaklah muncul secara tiba-tiba, melainkan ada faktor yang memicunya, namun faktor yang memicu tersebut tidak dapat kita pastikan secara nyata, melainkan harus melalui penelitian dan kajian ilmiah oleh para ahlinya. Jika kita merunut kepada sejarah, bahwa dimasa Rasulullah SAW wabah pun pernah terjadi dan menimbulkan korban jiwa. Penyakit yang datang dan melanda kehidupan manusia tidak pernah diharapkan apalagi sampai menimbulkan kekhawatiran, namun kita harus yakin setiap wabah ataupun musibah yang Allah berikan kepada

umat-Nya tentu memiliki hikmah yang terkandung didalamnya, terkandung bagaimana manusia menyikapi wabah atau musibah tersebut. Wabah penyakit yang melanda umat manusia sekarang pernah juga terjadi di zaman Rasulullah masih hidup. Wabah penyakit yang terjadi pada zaman Rasulullah adalah sejenis penyakit kusta, penyakit kusta ini juga termasuk penyakit keras, menular dan hingga menyebabkan kematian selain itu penyakit kusta ini dalam menjangkit manusia sangat cepat proses penyebarannya dimasa kala itu. Zaman Rasulullah selain penyakit kusta, ada juga wabah penyakit lain yaitu dimana masa Rasulullah melakukan hijrah ke Madinah, situasi di Madinah saat itu sangat mencemaskan dan mengkhawatirkan dengan kondisi air yang kotor, keruh dan penuh wabah penyakit.

Selain di zaman Rasullah wabah penyakit juga pernah melanda di masa para sahabat yaitu pada masa khalifah Umar bin Khatab, Khalifah Umar bin Khatab memutuskan untuk tidak melanjutkan perjalanan ke negeri Syam, hal ini terjadi setelah khalifah mendapat informasi dari Abdurrahman bin Auf bahwa suatu ketika Rasullah melarang seseorang untuk memasuki suatu wilayah yang terkena wabah penyakit. Maka dengan demikian dapat dipahami bahwa wabah penyakit ini bukan saja terjadi pada zaman modern seperti saat ini, tetapi pernah juga terjadi dimasa yang Rasulullah. Wabah penyakit yang melanda umat manusia sekarang dan masa lalu berbeda jenis wabah penyakitnya, namun proses penyebaran dan akibat dari wabah penyakit tersebut memiliki kesamaan misalnya, penyebarannya sangat cepat dan penderitanya bisa menyebabkan kematian. Berangkat dari sekilas sejarah wabah penyakit di atas maka selanjutnya kita kaitkan dengan kontek wabah virus corona atau covid19 yang sedang melanda dunia saat sekarang ini. ${ }^{3}$

Virus corona atau Covid 19 saat ini sedang melanda dunia yang bermula di akhir tahun 2019 dan awal tahun 2020 dan diprediksi berasal dari daratan China. Virus corona telah

${ }^{3}$ Tasri, "HIKMAH DI TENGAH WABAH VIRUS CORONA DALAM TINJAUAN HUKUM ISLAM", Qiyas Vol. Vol. 5, No. 1, April 2020 hlm. 44 
merenggut ribuan nyawa manusia selain itu penyebaran virus corona sangatlah cepat dan virus corona ini bisa menginfeksi sistem pernapasan sehingga korban mengalami sesak napas dan kejang-kejang hingga menyebabkan kematian. Virus corona pertama kali diidentifikasi sebagai penyebab flu biasa pada tahun 1960. Hingga sampai tahun 2002, virus itu belum dianggap fatal. Tetapi, pasca adanya Severe Acute Respiratory Syndrome (SARS-Cov) di China, para pakar mulai berfokus pada penyebab dan menemukan hasil apabila wabah ini diakibatkan oleh bentuk baru corona. Menurut world health organization (WHO), virus corona adalah sejenis virus yang menyebabkan flu biasa hingga mengakibatkan penyakit lebih parah seperti sindrom pernapasan Timur Tengah (MersCov) dan Sindrom pernapasan akut parah (Sar-cov). Bahkan ada dugaan virus corona merupakan penularan dari hewan ke manusia. Namun, kenyataan di lapangan bahwa virus corona juga menular dari manusia ke manusia.

Hingga saat ini belum ada vaksin untuk mencegah infeksi virus corona atau sering disebut Covid-19. Dalam rangka untuk mencegah penyebaran dan memutus rantai penularan virus corona khusus di Indonesia telah dilakukan berbagai cara, mulai dikeluarkannya kebijakan oleh pemerintah, baik pemerintah pusat hingga pemerintah daerah, misalnya dengan himbauan kepada seluruh masyarakat Indonesia untuk menjaga kebersihan diri dan kebersihan lingkungan sekitar, tidak melakukan aktivitas yang menyebabkan berkumpulnya banyak orang, kewajiban menggunakan masker saat keluar rumah, tidak melakukan bersentuhan (salaman dll), serta pemerintah menetapkan keputusan agar semua lapisan masyarakat agar tetap dirumah bahkan larangan untuk melakukan kegiatan mudik, selain itu sebagian daerah juga telah menerapkan Pembatasan Sosial Berskala Besar (PSBB). Semua hal ini dilakukan untuk memutuskan rantai dan penyebaran virus corona atau covid-19, selain itu juga untuk keselamatan, kenyamanan dan keamanan bersama. Namun realita di lapangan anjuran yang telah dikeluarkan pemerintah belum dilaksanakan secara maksimal oleh lapisan masyarakat, anjuran pemerintah tersebut tidak bisa ditaati secara maksimal dengan berbagai alasan misalnya, alasan ekonomi keluarga, alasan agama dan alasan lainnya. Tentu hal ini jika dibiarkan maka tujuan pemerintah untuk memutuskan rantai dan penyebaran virus corona di Indonesia belum bisa terwujud secara maksimal dan efektif. Dengan tidak dilaksanakan anjuran pemerintah oleh masyarakat, maka akan menimbulkan pro dan kontra dalam kehidupan masyarakat itu sendiri. Maka dari itu peran serta dari tokoh-tokoh agama, tokoh-tokoh masyarakat, pemerintah setempat dalam memberikan pemahaman kepada masyarakat yang kontra atas anjuran pemerintah tersebut, misalnya dengan melalui pendekatan persuasif. ${ }^{4}$

${ }^{4}$ Tasri, "HIKMAH DI TENGAH WABAH VIRUS CORONA DALAM TINJAUAN HUKUM ISLAM", Qiyas Vol. Vol. 5, No. 1, April 2020 hlm. 45 


\section{B. Kepedulian Sosial di Tengah Maraknya Penyakit Wabah Covid}

- Membantu Kesulitan dan Memberikan Kemudahan

Dalam kehidupan sosial sudah seharusnya seseorang menunjukkan kebaikan terhadap yang lainnya, hal ini memang sudah menjadi hukum alam bahwa jika seseorang melakukan kebaikan maka orang lainpun akan berbuat baik terhadap dirinya namun sebaliknya jika seseorang menunjukkan keburukan maka orang lainpun akan menunjukkan keburukan terhadap dirinya. Sudah sepatutnya sebagai seorang muslim selalu menjaga ikatan ukhuwah islamiyah melalui beberapa kegiatan kepedulian sosial. Diantaranya yakni membantu meringankan kesulitan yang dihadapi orang lain dan memberikan kemudahan kepadanya. Melalui sabdanya Rasulullah berulang kali menekankan supaya setiap muslim satu dan yang lainnya saling membantu.

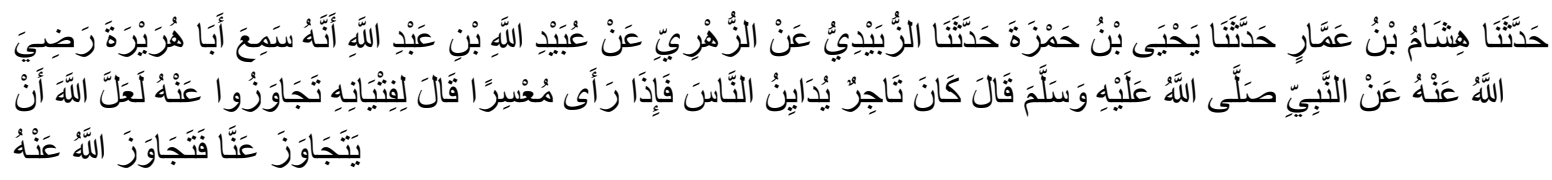

Telah menceritakan kepada kami Hisyam bin 'Ammar telah menceritakan kepada kami Yahya bin Hamzah telah menceritakan kepada kami Az Zubaidiy dari Az Zuhriy dari 'Ubaidullah bin 'Abdullah bahwa dia mendengar Abu Hurairah radliallahu 'anhu dari Nabi shallallahu 'alaihi wasallam bersabda: "Ada seorang pedagang yang memberi pinjaman kepada manusia sehingga jika ia melihat mereka dalam kesulitan dia berkata, kepada para pembantunya: "Berilah dia tempo hingga mendapatkan kemudahan semoga Allah memudahkan urusan kita. Maka kemudianAllah memudahkan urusan pedagang tersebut". (HR Bukhari kitab al-bai' bab memberi tempo orang kesuitan) ${ }^{5}$

\section{- Bersedakah}

Mengeluarkan sedekah pada setiap saat yang merupakan perbuatan sunnat dilakukan menurut ijma' ulama, dan Islam mengajak manusia untuk berkorban harta, memberikan dorongan kepadanya dengan gaya bahasa yang memikat hati, membangkitkan semangat jiwa, dan menanamkan nilai- nilai kebaikan didalam hati. Sedekah disunnahkan bagi orang yang memiliki kelebihan harta, yaitu dari biaya untuk dirinya sendiri dan biaya orang-orang yang dinafkahkan.

${ }^{5}$ Imam Abi ‘Abdillah Muhammad bin Isma'il al-Bukhariy, Shahîh Bukhari, (Dar Ibn Katsir: Dimasyq Beirut, tt) Jilid II hlm. 731 
Rasulullah SAW bersabda

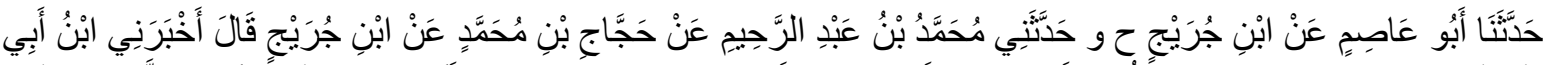

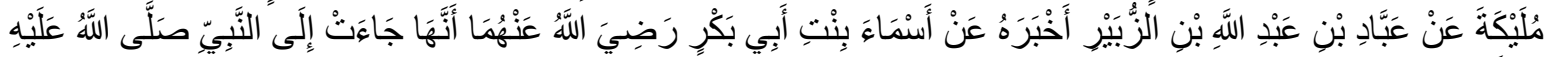

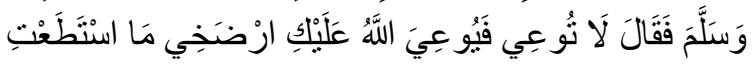

"Telah menceritakan kepada kami Abu 'Ashim dari Ibnu Juraij. Dan diriwayatkanpula telah menceritakan kepada saya Muhammad bin 'Abdur Rahim dari Hajjaj bin Muhammad dari Ibnu Juraij berkata, telah mengabarkan kepada saya Ibnu Abu Mulaikah dari 'Abbad bin 'Abdullah bin Az Zubair bahwa dia mengabarkannya dari Asma' binti Abu Bakar radliallahu 'anhuma bahwa dia menemui Nabi Shallallahu 'alaihi wasallam lalu Beliau bersabda: "Janganlah kamu berkarung-karung (kamu kumpulkan harta dalam karung lalu kamu untuk menginfaqkannya) sebab Allah akan menyempitkan reziki bagimu dan berinfaqlah dengan ringan sebatas kemampuanmu." (H.R Bukhari)

Sedekah adalah pemberian harta kepada orang-orang fakir, orang yang membutuhkan ataupun pihak-pihak lain yang berhak menerima sedekah tanpa disertai imbalan dari orang lain dan hanya mengharap ridla Allah Swt. Dengan bersedekah, harus disertai taubat atas dosa yang pernah dilakukan. ${ }^{6}$

\section{Proteksi Diri Saat Pandemi COVID 19}

Menurut ajaran Islam, menjadi coronavirus carrier sama bahayanya dengan menjadi korban pandemi Covid-19. Dua-duanya harus dihindari. Kebijakan pemerintah pusat di beberapa negara di dunia menerapkan lockdown (karantina wilayah secara total) atau kebijakan pemerintah negara bagian atau daerah seperti di Indonesia memberlakukan PSBB (Pembatasan Sosial Berskala Besar). Substansi dari lockdown dan PSBB adalah penutupan akses masuk ke, dan keluar dari, satu daerah yang terdampak Covid19. Tujuan utama dari implementasi kedua kebijakan itu adalah sama-sama untuk mempercepat memutus mata rantai penyebaran Covid-19. Orang yang banyak berdo'a bukan hanya akan dikabulkan berbagai permintaannya, seperti agar dihindarkan atau dilindungi oleh Allah Swt. dari pandemi Covid-19, tapi dia juga dinilai sebagai orang yang banyak melakukan ibadah, karena berdo'a adalah ibadah. Terkadang ada beberapa kelompok masyarakat yang salah memahaminya.

${ }^{6}$ Al-Bukhari, Al-Imam Abu Abdullah Muhammad bin Ismail, Shahih Bukhari Terj. Ahmad Sunarto, (Semarang: CV. Asy Syifa'). hlm, 350. 
Dalam kontek bertawakal yang benar, usaha itu harus ada walaupun dalam wujudnya yang sangat sederhana, sebagaimana datangnya rezeki kepada burung dengan sekedar terbang pergi di pagi hari dari, dan pulang di sore hari ke, sarangnya. Mahluk Allah Swt. yang bernama manusia yang bertakwa dan bertawakal sepenuhnya kepada Allah telah mendapat jaminan dari Allah untuk mendapatkan kecukupan atas apa yang dibutuhkannya. Kesunggguhan bertawakal dalam memproteksi diri dari pandemi Covid-19 dalam pelaksanaannya tidak bertentangan dengan melakukan berbagai upaya sebagaimana diatur oleh pemerintah melalui berbagai peraturan sebagai sebab yang mana Allah menakdirkan segala sesuatu dengannya dan dengannya pula berjalan sunnah-Nya pada makhluk-Nya, yaitu sebab-akibat. Bila diperhatikan secara mendalam, sebenarnya perintah Allah Swt. untuk melakukan suatu tidakan yang menjadi sebab itu bersamaan dengan perintah-Nya untuk bertawakal. Karena itu, mengusahkan berbagai tindakan untuk memperoteksi diri dari pandemi Covid-19 sebagai sebab dengan dengan fisik adalah suatu bentuk ketaatan kepada Allah Swt., sedangkan tawakal dengan hati merupakan bentuk keimanan kepada Allah. Penggunaan masker dalam kehidupan sehari-hari di waktu pandemi Covid-19 sesuai dengan semangat ajaran.

Karena, penggunaan masker memiliki tujuan akhir yang sama dengan menutup bejana, yaitu agar fisik kita tidak terpapar virus melalui hidung dan mulut yang keduanya merupakan alat pernapasan bagi manusia. Bejana air harus dittutup agar virus tidak masuk ke dalam air yang pada akhirnya menyerang manusia yang menggunakan air itu. Dengan demikian menggunakan masker dalam keseharian pada masa-masa pandemi Covid19 bernilai ibadah sepanjang diniatkan untuk melaksanakan perintah ajaran Agama Islam yang terdapat dalam Hadits shahih itu untuk menjaga diri agar tidak terpapar Covid-19. Bila tangan senantiasa dicuci, maka tangan akan steril, dan jika sudah steril tangan dapat digunakan untuk melakukan berbagai aktivitas, termasuk, jika diperlukan, menyentuh wajah. Perspektif Islam tentang itu melintasi dunia sampai akhirat; efek dari konsumsi itu eksis dari alam fana sampai alam baka. Siapa pun yang menkonsumsi makanan dan minuman yang halal, sehat, lezat, dan bergizi, tidak hanya alan tampil sebagai pribadi yang sehat jasmaninya, tapi juga ruhaninya. Tidak hanya akan selamat dari neraka dunia (sakit), tapi juga akan selamat dari jilatan api neraka di akhirat nanti. Di dunia sehat dan bahagia di akhirat menikmati kenikmatan yang kekal dan abadi, kenikmatan di alam surga. Optimisme merupakan satu elemen penting yang harus hadir pada jiwa setiap individu untuk bisa mengarungi kehidupan dengan baik dan mulus. Dalam perspektif Islam, optimisme itu merupakan bagian dari berbaiksangkanya seorang hamba kepada Allah. ${ }^{7}$

7 Tajul Arifin, dkk, "Proteksi Diri Saat Pandemi COVID-19 Berdasarkan Hadits Shahih", diakses dalam https://core.ac.uk/download/pdf/327164615.pdf hlm. 9 
Agama dan ajaran Islam menaruh perhatian amat tinggi pada kebersihan, baik lahiriah (fisik) maupun batiniyah (psikis). Kebersihan lahiriyah itu tidak dapat dipisahkan dengan kebersihan batiniyah. Oleh karena itu, ketika seorang Muslim melaksanakan ibadah tertentu harus membersihkan terlebih dahulu aspek lahiriyahnya. Ajaran Islam yang memiliki aspek akidah, ibadah, muamalah, dan akhlak ada kaitan dengan seluruh kebersihan ini. Hal ini terdapat dalam tata cara ibadah secara keseluruhan. Orang yang mau shalat misalnya, diwajibkan bersih fisik dan psikhisnya. Secara fisik badan, pakaian, dan tempat shalat harus bersih, bahkan suci. Secara psikhis atau akidah harus suci juga dari perbuatan syirik. Manusia harus suci dari fahsya dan munkarat. Kebersihan merupakan bagian dari iman, kebersihan didalam Islam memiliki berbagai aspek kehidupan manusia baik dari aspek ibadah maupun aspek moral dan aspek sosial, dalam Islam kebersihan sering digunakan dengan istilah "bersuci" kata bersuci merupakan padanan kata "membersihkan/melakukan kebersihan". Kebersihan selain dicintai dan disukai oleh Allah SWT kebersihan juga memberikan manfaat kepada manusia, jika badan dan lingkungan bersih maka kita akan terhindar dari segala macam penyakit.

Namun sebaliknya, jika badan dan lingkungan kotor maka berbagai penyakit akan mudah menyerang kesehatan tubuh manusia. Selain kebersihan lingkungan dan kebersihan diri agama dan ajaran Islam juga mengajarkan kepada umatnya untuk memakan dan minum yang halal, baik, sehat, dan banyak mengandung gizi maupun protein. Tidak ada suatu musibah pun yang menimpa seseorang pada dirinya, hartanya atau anaknya melainkan dengan kada dan takdir Allah. Merujuk pada ayat tersebut di atas yang dikaitkan dalam konteks sekarang, dengan adanya virus corona merupakan salah satu cobaan. Semua orang dibuat takut dan khawatir oleh penyebaran virus covid 19 ini. Oleh sebab itu, sikap yang diambil adalah meyakini bahwa virus adalah makhluk Allah, tunduk dan taat atas perintah Allah SWT. Dengan demikian, manusia diharuskan kembali kepada jati dirinya yaitu ada Yang Maha Kuasa dibalik semua kejadian di muka bumi ini. Sikap selanjutnya adalah berdoa, karena kekhawatiran akan menyebarnya virus corona bukan menjadikan paranoid, sebagai insan beriman kita harus yakin bahwa semua itu atas kehendak-Nya, maka berdoa agar selamat dan dijaga dari penyebaran penyakit akibat virus corona menjadi sesuatu yang harus kita mohonkan kepada Allah SWT. 
Sikap selanjutnya sesuai dengan apa yang dianjurkan oleh Rasulullah Muhammad SAW. Namun dibalik wabah virus corona yang melanda dunia saat sekarang ini ada sekelompok masyarakat yang tidak memperdulikan himbauan maupun intruksi pemerintah. Masyarakat yang tidak merespon dengan baik himbauan dari pemerintah dengan berbagai alasan, misalnya faktor ekonomi keluarga, faktor sosial, faktor agama dan faktor lainnya. Kesadaran masyarakat dengan tidak menaati aturan yang telah dikeluarkan pemerintah, dikemudian hari akan berdampak tidak bagus bagi masyarakat itu sendiri. Maka untuk memberikan pemahaman dan pengetahuan kepada masyarakat akan pentingnya physical distance atau jaga jarak fisik antar satu sama lainnya merupakan perlu peran semua pihak, mulai dari tokoh agama, tokoh masyarakat dan lembaga lain bahu membahu dalam mewujudkan keinginan pemerintah tersebut.Hikmah ditengah wabah virus corona (covid 19) dalam kehidupan manusia sehari-hari Setiap musibah yang dialami ogaimana cara kita menyikapi dan menghadapinya. Termasuk wabah penyakit virus corona juga merupakan ketentuan dan kehendaka dari Allah SWT, tetapi kita sebagai manusia harus yakin dan percaya bahwa setiap musibah yang menimpa seseorang ataupun sekelompok orang ada pelajaran atau hikmah yang dapat kita petik. Wabah virus corona yang sedang melanda dunia saat ini tentu memiliki hikmah tersendiri bagi manusia itu sendiri, hikmah virus corona atau covid 19 tersebut meliputi:

1. Dengan adanya virus corona manusia dianjurkan untuk makan dan minum yang halal, baik, sehat dan bergizi;

2. Dengan adanya virus corona manusia harus memperoleh dan mengolah makanan dan minuman sesuai dengan ketentuan syariah, misalnya tidak memakan makanan yang tidak dimasak secara sempurna, tidak memakan makanan yang bisa mengundang penyakit misalnya makan tikus, ular, kelelawar dan hewan lainnya;

3. Dengan adanya virus corona manusia harus menjaga kebersihan, baik kebersihan lahir dan kebersihan bathin misalnya menjaga kebersihan diri, pakaian, lingkungan dan menerapkan pola hidup sehat. Selain itu manusia juga harus bias mengendalikan emosi dan amarahnya dalam menghadapi berbagai masalah misalnya jangan mudah panik, jangan mudah terprovokasi dengan kabar atau berita yang tidak bertanggungjawab.

4. Dengan adanya virus corona manusia harus banyak melakukan aktivitas positif dan menjauhi aktivitas negatif. Aktivitas positif misalnya berolahraga secara teratur, beribadah, berbuat kebaikan (sedekah, infak atau sumbangan) kepada yang membutuhkan dan aktivitas positif lainnya, sedangkan Aktivitas negatif misalnya minuman keras, perjudian, perzinaan dan aktivitas negative lainnya.

5. Dengan adanya virus corona bisa mempertebal keimanan kita dan menyakinkan bahwa Allah SWT Maha Kuasa atas segalanya; 
6. Dengan adanya virus corona manusia harus melaksanakan anjuran, himbauan dan perintah pemimpin (ulil amri) selama perintahnya dalam melakukan hal kebaikan;

7. Manusia harus yakin bahwa musibah atau wabah penyakit yang melanda manusia saat ini merupakan peringatan dari Allah SWT agar kita senantiasa berada dijalan-Nya;

8. Manusia harus selalu berikhtiar, berdoa dan tawakal kepada-Nya;

9. Dan Manusia harus yakin bahwa wabah atau musibah yang sedang melanda umat manusia saat ini akan segera berakhir dengan izin-Nya. ${ }^{8}$

${ }^{8}$ Tasri, "HIKMAH DI TENGAH WABAH VIRUS CORONA DALAM TINJAUAN HUKUM ISLAM", Qiyas Vol. Vol. 5, No. 1, April 2020 hlm. 46 


\section{Kesimpulan}

Tidak ada batas maksimal ataupun minimal dalam mengerjakan kebaikan, selagi hal tersebut bias memberikan manfaat maka dianjurkan untuk melakukannya. Setiap kebaikan yang dilakukan tidak memandang ras, agama, bahasa maupun suku. Dalam artian berbuat baik adalah hak semua orang, tidak ada batasan berbuat baik ditunjukkan kepada orang tertentu dalam hal ini seseorang dituntut untuk memiliki rasa toleransi di berbagai bidang kehidupan terutama dalam mengerjakan kebaikan. Toleransi mengandung pengertian kesediaan menerima kenyataan pendapat yang berbeda-beda tentang kebenaran yang dianut. Dapat menghargai keyakinan orang lain terhadap agama yang dipeluknya, serta memberikan kebebasan untuk menjalankan apa yang dianutnya dengan tidak bersikap mencela ataupun memusuhinya. Islam menghargai toleransi dan perlu dikembangkan agar antarumat beragama hidup berdampingan secara damai dan sikap saling terbuka sehingga iklim saling pengertian dapat tercapai. Islam menyatakan supaya menghormati dan menghargai penganut agama yang berbeda, dan mengajarkan amar ma'ruf nahi munkar (perintah melakukan kebaikan dan mencegah melakukan kejahatan), mengarahkan supaya hidup rukun, hidup sejahtera material dan spiritual. Allah memberikan tuntunan dan kebahagiaan hidup di dunia dan akhirat. Allah menyatakan kehendaknya melalui ajaran agama guna menjadi pegangan umat manusia dalam hidupnya. Ajaran agama memberikan pedoman mengenai hubungan manusia dengan Tuhan Yang Maha Esa, dengan diri sendiri, dengan sesama manusia dan dengan alam sekitarnya termasuk di dalamnya bermasyarakat, bernegara dan bertanah air. Selanjutnya berikut ini perlu ditunjukkan rangakaian sikap-sikap umat Islam dalam kehidupan beragama di dalam NKRI berdasarkan Pancasila dan UUD 1945. Budaya gotong royong adalah realitas sejarah sejak Islam belum datang. Semua upaya masyarakat dan pemerintah dalam menangani Covid19 terus melakukan kerja sama dan tanggung jawab masing-masing dengan berbagai macam langkah-langkah meliputi menjauhkan diri dari wabah, senantiasa memohon perlindungan kepada Allah, tawakal kepada Allah, menggunakan masker setiap saat, selalu mencuci tangan, mengkonsumsi makanan dan minuman yang halal, sehat, lezat, dan bergizi, dan optimis bahwa Allah akan mengakhirinya. 


\section{Daftar Pustaka}

Abulsyani. (2012). Sosiologi Skematika Teori dan Terapan. Jakarta: PT Bumi Aksara.

Al-Bukhari, A.-I. A. (tth). Shahih Bukhari Terj. Ahmad Sunarto. Semarang: CV. Asy Syifa.

al-Bukhariy, I. A. (tth). Shahih Bukhari. Dimasyq Beirut: Dar Ibn Katsir.

Mahmudi, I. (tth). ISLAM, BUDAYA GOTONG ROYONG DAN KEARIFAN LOKAL. Penguatan Komunitas Lokal Menghadapi Era Global Strengthening Local Communities Facing the Global Era, 450-458.

Tajul Arifin, d. (tth). Proteksi Diri Saat Pandemi COVID-19 Berdasarkan Hadits Shahih. $1-15$.

Tasri. (2020). HIKMAH DI TENGAH WABAH VIRUS CORONA DALAM TINJAUAN HUKUM ISLAM. Qiyas Vol. Vol. 5, No. 1 , 42-50. 